\title{
Patterns of vertical distribution in epipelagic heteropod molluscs off Hawaii
}

\author{
Roger R. Seapy \\ Department of Biological Science, California State University, Fullerton, California 92634, USA
}

\begin{abstract}
Diel patterns of vertical distribution were assessed for 13 species of heteropod molluscs from the epipelagic zone oft Hawaii. Replicated series of oblique tows were taken through 5 depth intervals to $300 \mathrm{~m}$ using opening-closing, $70 \mathrm{~cm}$ Bongo nets during day and night periods. Two species (Atlanta fusca and Oxygyrus keraudreni) were restricted to the upper $90 \mathrm{~m}$ of the water column and were captured in low numbers. Five species (A. lesueuri, A. inflata, Firoloida desmaresti, A. helicinoides and $A$. oligogyra) ranged from the surface to $140 \mathrm{~m}$ during either or both diel periods. There were no evident diel differences in vertical distribution among these species, with the exception of $A$. helicinoides, which appeared to undergo a limited upward migration at night. Three species (Protatlanta souleyeti. A. turriculata and A. plana) had daytime distributions extending to $200 \mathrm{~m}$. Limited upward migrations at night were suggested for the latter 2 species. Lastly, 3 species (Pterotrachea hippocampus, A. peroni and A. meteori) ranged below $200 \mathrm{~m}$ during the day. These species achieved the largest sizes recorded in this study in their respective families, and exhibited upward nocturnal migrations. A series of 6 oblique, open-net tows to a target depth of $50 \mathrm{~m}$ with $70 \mathrm{~cm}$ Bongo nets and a $4 \mathrm{~m}^{2}$ ring net suggested that several species are capable of daytime net avoidance, implying that the low daytime densities recorded for these species from shallow waters during the vertical distribution study couid have represented, at least in part, sampling artifacts. Results of this study suggest that the majority of Hawaiian heteropods are small non-migrators that dwell in the upper $140 \mathrm{~m}$ of the water column. This distributional pattern is supported by in situ behavioral observations on shallow-water atlantids, which indicate that these animals are active during the day and inactive at night. In contrast, the species of heteropods that ranged the deepest in the water column attained the largest sizes and underwent upward, nocturnal vertical migrations. The migrating members of these populations may feed at night on bioluminescent prey.
\end{abstract}

\section{INTRODUCTION}

The heteropods are holoplanktonic gastropod molIuscs that dwell primarily in the epipelagic zone of the water column (Tesch 1949, van der Spoel 1976, Raymont 1983). Several species of carinariid and pterotracheid heteropods, however, have been recorded from the mesopelagic zone using opening-closing nets (Pafort-van Iersel 1983). Data regarding the vertical distribution of epipelagic heteropods are very limited. One species of pterotracheid, Firoloida desmaresti, was shown (Blackburn 1956) to form a sonic scattering layer at a depth of $20 \mathrm{~m}$ in waters off Australia. Open-net tows were taken from the surface to $100 \mathrm{~m}$ and the surface to between 200 and $400 \mathrm{~m}$ in the Indian Ocean by Richter (1974). Differences in the abundances of 6 species of atlantids captured by the 2 types of tows suggested that 3 species preferred waters shallower than $100 \mathrm{~m}, 2$ preferred waters deeper than $100 \mathrm{~m}$, and
1 showed no preference. Two studies (Thiriot-Quiévreux 1968, Taylor \& Berner 1970) utilized closing nets to sample heteropods in the epipelagic zone. However, results were inconclusive, either because of an inadequate sample size (the former paper; in which a finemesh net was used to sample larvae) or the absence of sample replication (the latter paper). The only openingclosing net study to yield adequate data was by Richter (1982) for the atlantid Oxygyrus keraudreni from the Indian Ocean. Richter reported that this species was essentially limited to the upper $100 \mathrm{~m}$ of the water column during both day and night periods, with most individuals occurring in the upper $50 \mathrm{~m}$. Thus, aside from $O$. keraudreni, patterns of vertical distribution for the epipelagic heteropods are unknown.

The present paper reports diel patterns of vertical distribution for 13 species of epipelagic heteropods from Hawaiian waters. The results are based on a series of replicated tows through a series of 5 depth 
intervals to a maximal depth of $300 \mathrm{~m}$ (i.e. through most of the $400 \mathrm{~m}$ epipelagic zone in Hawaiian waters; Young et al. 1980).

\section{MATERIALS AND METHODS}

All plankton samples used in this study were collected off the southwest side of the Hawaiian island of Oahu (Fig. 1) from waters overlying the $2000 \mathrm{~m}$ bottom depth contour at a distance of 11 to $20 \mathrm{~km}$ from the island $\left(21^{\circ} 15^{\prime} \mathrm{N}, 158^{\circ} 20^{\prime} \mathrm{W}\right)$. Research vessels of the University of Hawaii, the RV 'Kana Keoki' and RV 'Kila', were used in the 1984 and 1986 cruises, respectively.

Distribution study - stratified tows. Diel patterns of vertical distribution were assessed from 36 tows taken with opening-closing, paired, $70 \mathrm{~cm}$ Bongo nets between 10 and $14 \mathrm{April}$ 1984. The Bongo nets were constructed of Nytex cloth having a mesh size of $0.5 \mathrm{~mm}$. This mesh size is sufficiently fine for sampling adult atlantids, since the minimal shell diameter at which metamorphosis occurs is 0.6 to $0.7 \mathrm{~mm}$ (Seapy in press). The depth range of each tow was determined using a Benthos Time-Depth Recorder, and the volume of water filtered was computed from flow meter readings taken with a T.S.K. Model OI-210 Flow Meter. Each tow was about 30 min in duration and was oblique through each of the targeted depth intervals $10-50$, $50-100, \quad 100-150, \quad 150-200$ and $200-300 \mathrm{~m}$ ). Towing depth was less consistent as depth increased because we had no means of continuously monitoring the depth of the net. Instead, during each tow the wire angle was measured with a hand-held wire angle indicator and the approximate length of cable required to reach the

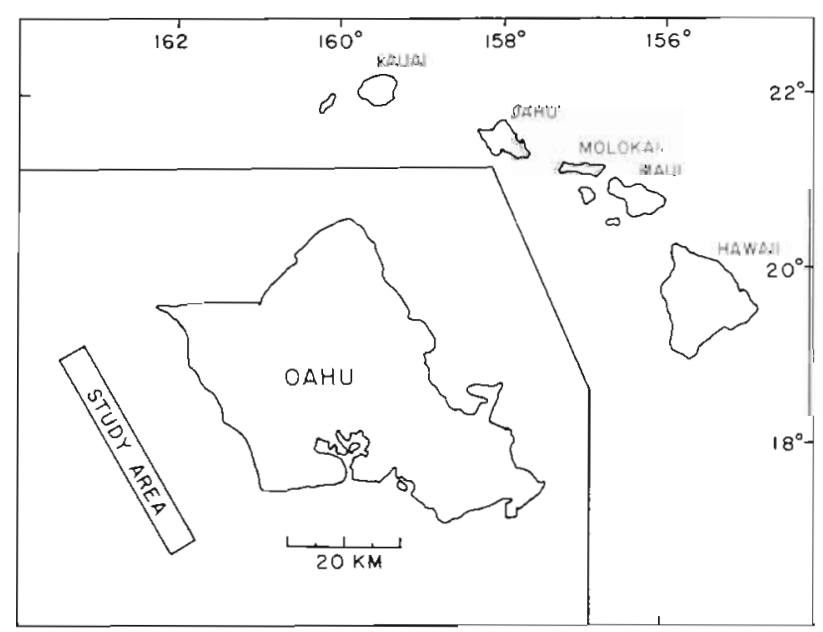

Fig. 1. Location of the island of Oahu in the Hawaiian Archipelago and (inset) the study area off the southwest coast of the island $\left(21^{\circ} 15^{\prime} \mathrm{N}, 158^{\circ} 20^{\circ} \mathrm{W}\right)$ target depth was subsequently calculated. The depth ranges of individual tows were close to the targeted depths at shallower levels, but became less accurate as depth increased (Fig. 2). For purposes of data analysis, tows which fished predominantly within one depth interval are considered to be totally within that interval, while tows that ranged only through part of a depth interval are also considered to have fished that entire interval. Thus, each tow was assigned to one of the depth intervals indicated in Fig. 2.

The densities of each species in each depth interval during day and night periods were compared using the Mann-Whitney U test (Daniel 1978). Within each depth interval shell diameters were determined for each species and the resultant size-frequency distributions were compared between day and night periods using the Kolmogorov-Smirnov 2-sample test (Daniel 1978).

Capture records for three of the species (Atlanta inclinata, Carinaria galea and Pterosoma planum) were inadequate for the analysis of vertical distribution. Single specimens of $A$. inclinata were collected by 2 of the $0-45 \mathrm{~m}$ day tows, while one $P$. planum and one C. galea were captured in $0-45 \mathrm{~m}$ and $45-90 \mathrm{~m}$ night tows, respectively.

Net avoidance study - oblique tows. Preliminary results indicated that a number of species occurred in low densities in the shallow, $0-45 \mathrm{~m}$ tows during the day. To test for the possibility that these low densities could have resulted from net avoidance, oblique, opennet tows of ca 30 min duration were taken between $10: 31$ and $16: 22 \mathrm{~h}$ on 23 November 1986 using the

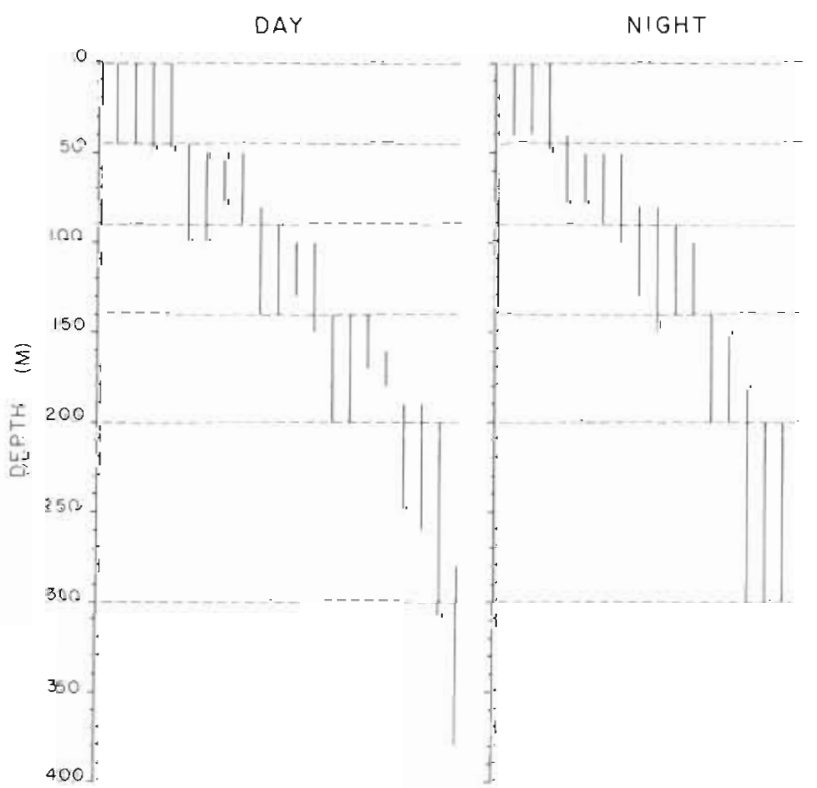

Fig. 2. Depth ranges of Bongo net tows taken during day and night periods during 9 to 15 April 1984. Horizontal dashed lines indicate the depths selected to partition the water column into sample depth intervals 
Bongo nets and a large ring net. Three tows were taken with the paired Bongo nets (mouth diameter $=70 \mathrm{~cm}$; combined mouth area $=0.77 \mathrm{~m}^{2}$ ), followed by 3 tows with the ring net (mouth diameter $=2.26 \mathrm{~m}$; mouth area $=4.0 \mathrm{~m}^{2}$ ). The mesh size of the Nytex cloth for both types of nets was $0.5 \mathrm{~mm}$. A Benthos Time-Depth Recorder and T.S.K. flowmeter were used during each tow. The Bongo nets filtered an average of $1417 \mathrm{~m}^{3}$, while the ring net filtered a mean of $5112 \mathrm{~m}^{3}$. The maximal depth fished by the ring net was somewhat greater (average $=50 \mathrm{~m}$ ) than the Bongo nets (average $=40 \mathrm{~m}$ ). Because of the low number of replicates, species densities from the Bongo and ring nets could not be compared statistically.

As an indication of whether any of the heteropod species were able to avoid capture by the large ring net during the day, data from a 24 to 25 March 1986 cruise were utilized. A day-night series of 15 oblique tows of about 30 min duration were taken with the ring net to a target depth of $300 \mathrm{~m}$. Seven daytime tows were followed by 8 night-time tows. The volume of water filtered by the net averaged $6973 \mathrm{~m}^{3}$ (range $=5820$ to $7665 \mathrm{~m}^{3}$ ). Maximal tow depth averaged $305 \mathrm{~m}$ (range $=$ 240 to $340 \mathrm{~m}$ ). Density differences between diel periods were compared for each species using the Mann Whitney U test.

Sample processing. All samples were preserved in $4 \%$ buffered, seawater-formalin solution. After 24 to $48 \mathrm{~h}$ the samples were transfered to $40 \%$ isopropanol solution. Specimens were identified, enumerated and shell diameters determined under a Wild M5 Stereoscopic Dissection Microscope. Measurements of shell diameter were made with the aid of an ocular micrometer and do not include the keel, which commonly was partially to entirely broken off, particularly along the posterior margin of the shell. The species of atlantid and pterotracheid heteropods included in this study have been characterized elsewhere (Seapy 1985, 1987, in press).

\section{RESULTS}

\section{Diel patterns of vertical distribution}

Results are presented for 13 species of heteropods. These species were partitioned among 4 groups on the basis of their daytime vertical ranges: 0 to $90 \mathrm{~m}, 0$ to $140 \mathrm{~m}, 0$ to $200 \mathrm{~m}$ and 0 to $300 \mathrm{~m}$.

Two species, Atlanta fusca and Oxygyrus keraudreni, were limited to the upper $90 \mathrm{~m}$ of the water column (Figs. 3 and 4). For both species low numbers were captured during both day and night periods. The mean density of $A$. fusca was about twice as great in the $0-45 \mathrm{~m}$ depth interval as in the $45-90 \mathrm{~m}$ interval (Fig. 3). There were no significant differences in

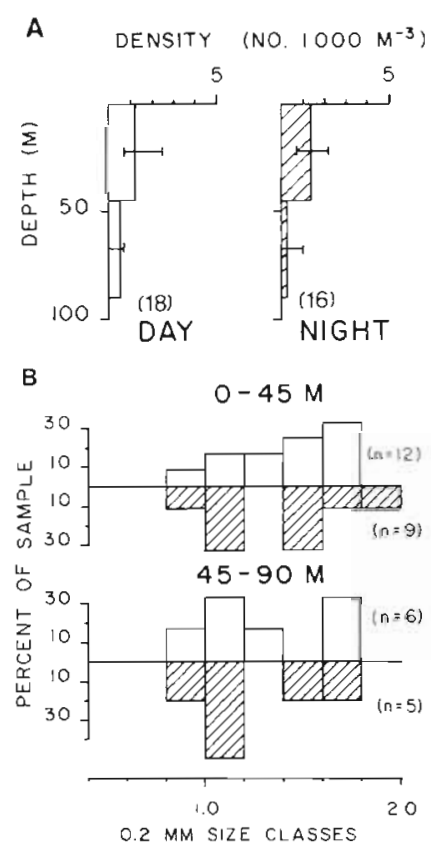

Fig. 3. Allanta fusca. (A) Mean densities (numbers $1000 \mathrm{~m}^{-3}$ ) during day (open plots) and night (hatched plots). Ranges in densities among replicates are indicated by horizontal bars at the midpoint of each depth interval. Total numbers of specimens collected by day and night shown in parentheses. (B) Percentage of individuals collected in different size classes during the day (open bars above the horizontal) and at night (hatched bars below the horizontal) in each depth interval. $n$ : number of measured specimens

density or size between day and night periods in either the $0-45$ or $45-90 \mathrm{~m}$ intervals. Eight of the 9 individuals of $O$. keraudreni captured were taken in the upper $45 \mathrm{~m}$ (Fig. 4). In this depth interval there were no significant differences between day and night periods for density or size, although the mean density was 3 times higher at night and individuals belonging to size classes larger than $1.4 \mathrm{~mm}$ were captured only at night.

The vertical ranges of 5 species (Atlanta lesueuri, $A$ inflata, Firoloida desmaresti, $A$. helicinoides and $A$. oligogyra) extended from the surface to $140 \mathrm{~m}$ during one or both of the diel periods (Figs, 5 to 9, respectively). Except for the pterotracheid F. desmaresti, all of the remaining species in this group were small atlantids of less than $2.0 \mathrm{~mm}$ in shell diameter. A. lesueun was the most abundant species encountered in the study, attaining a maximal density of 59 individuals per $1000 \mathrm{~m}^{3}$ in one of the $0-45 \mathrm{~m}$ daytime tows (Fig. 5). Comparisons of densities between diel periods for each depth interval revealed no significant differences. High replicate variability in densities was recorded for nearly all depth intervals, and no inferences can be made about diel movements. Shell diameters ranged narrowly from 0.6 to $2.0 \mathrm{~mm}$ and did not differ significantly between day and night periods. 

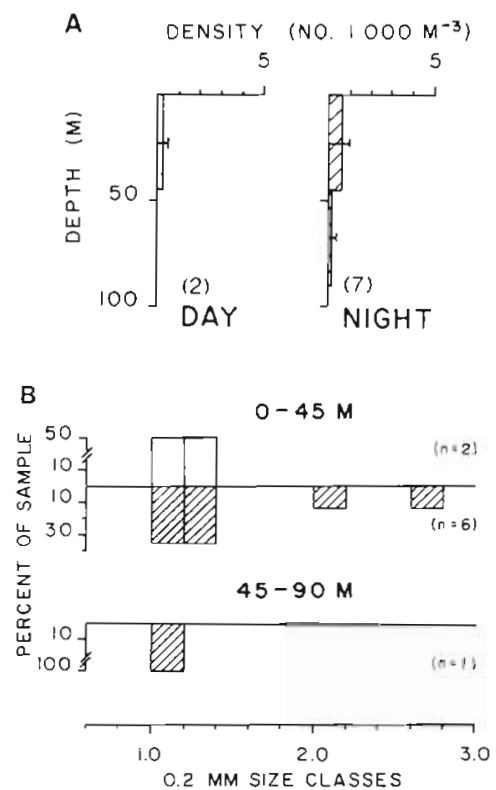

Fig. 4. Oxygyrus keraudreni. Legend as for Fig. 3

Like Atlanta lesueuri, $A$. inflata exhibited high replicate variability in nearly all depth intervals (Fig. 6). No significant differences in density were obtained between day and night periods for any of the depth intervals. Small specimens (1.6 to $2.6 \mathrm{~mm}$ ) were captured from all 3 depth ranges, and no day-night differences in size frequencies were determined. Firoloida desmaresti also exhibited high variability between sample replicates (Fig. 7). There were no significant density or size differences between day and night periods for any of the depth intervals. Although there was no significant diel difference in size in the 0-45 m interval, there was a noticeable shift in the size classes captured at night ( 4 to $20 \mathrm{~mm}$ ) compared with the day (10 to $24 \mathrm{~mm})$.

Atlanta helicinoides was most abundant in the 0-45 $\mathrm{m}$ interval during both day and night periods (Fig. 8). This species did not exceed $2.0 \mathrm{~mm}$. There were no significant diel differences in density or size for any of

A

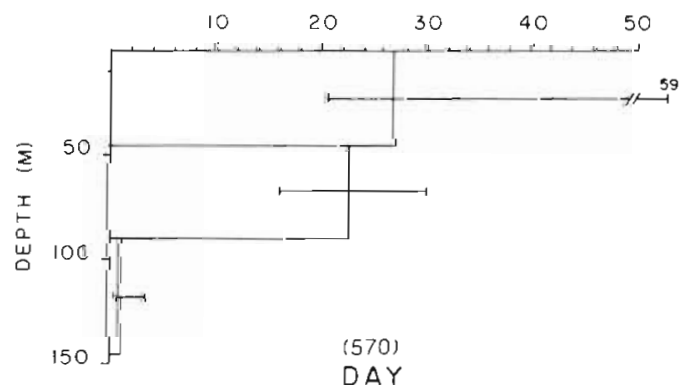

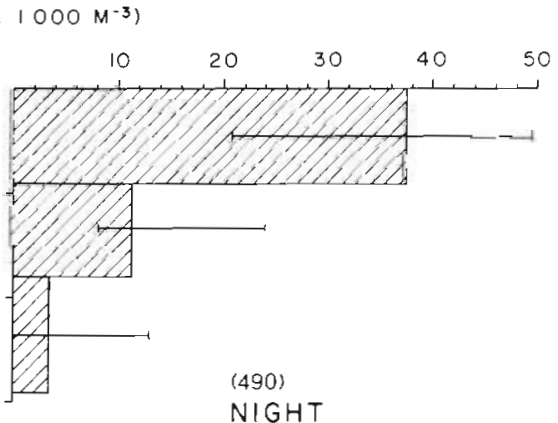

NIGHT the depth intervals. Nonetheless, nearly all of the individuals collected at night were present in the upper $45 \mathrm{~m}$ of the water column which, although not supported statistically, is at least suggestive of a limited upward nocturnal migration by the deeper members of the population. A oligogyra was captured in very low numbers from all depth intervals (Fig. 9). The maximal size for this species was $1.9 \mathrm{~mm}$. No significant diel differences in density or size were obtained for any of the depth intervals.

Three species (Protatlanta souleyeti, Atlanta turriculata and $A$. plana) ranged to $200 \mathrm{~m}$ during the day (Figs. 10 to 12, respectively). Like the preceding species of atlantids, the specimens of $P$. souleyeti and A. turriculata collected in the Bongo net samples were small, having a maximal size of less than $2 \mathrm{~mm}$. $P$. souleyeti exhibited high replicate variability in the depth intervals below $45 \mathrm{~m}$ (Fig. 10). No significant differences in density were found between day and night periods, except for the $0-45 \mathrm{~m}$ interval where significantly higher densities occurred at night. The size-frequency data for each depth interval were comparable between diel periods and were not significantly different, although there was a general upward shift in the size classes of individuals captured at night in the $0-45 \mathrm{~m}$ interval. This apparent night-time size increase may not be real, however, since such low numbers $(\mathrm{n}=2)$ were captured in this depth interval during the day The density data for A. turriculata (Fig. 11) suggest an upward migration from deeper waters $(90$ to $200 \mathrm{~m}$ ) during the day to shallower waters $(0$ to $90 \mathrm{~m})$ at night. Replicate variability was high, however, and a significant difference between day and night densities was obtained only for the $45-90 \mathrm{~m}$ depth interval. Size-frequency distributions in each depth interval were comparable between day and night periods and were not significantly different.

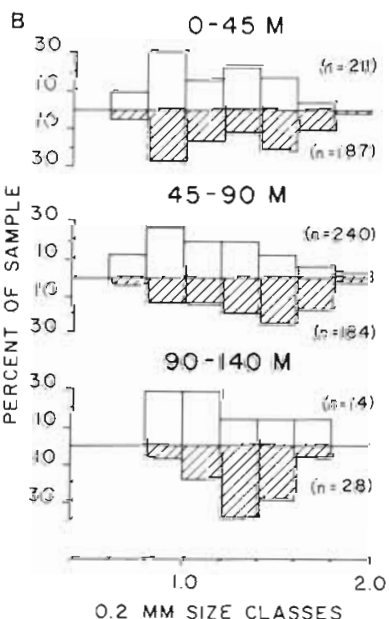

Fig. 5. Atlanta lesueuri. Legend as for Fig. 3 

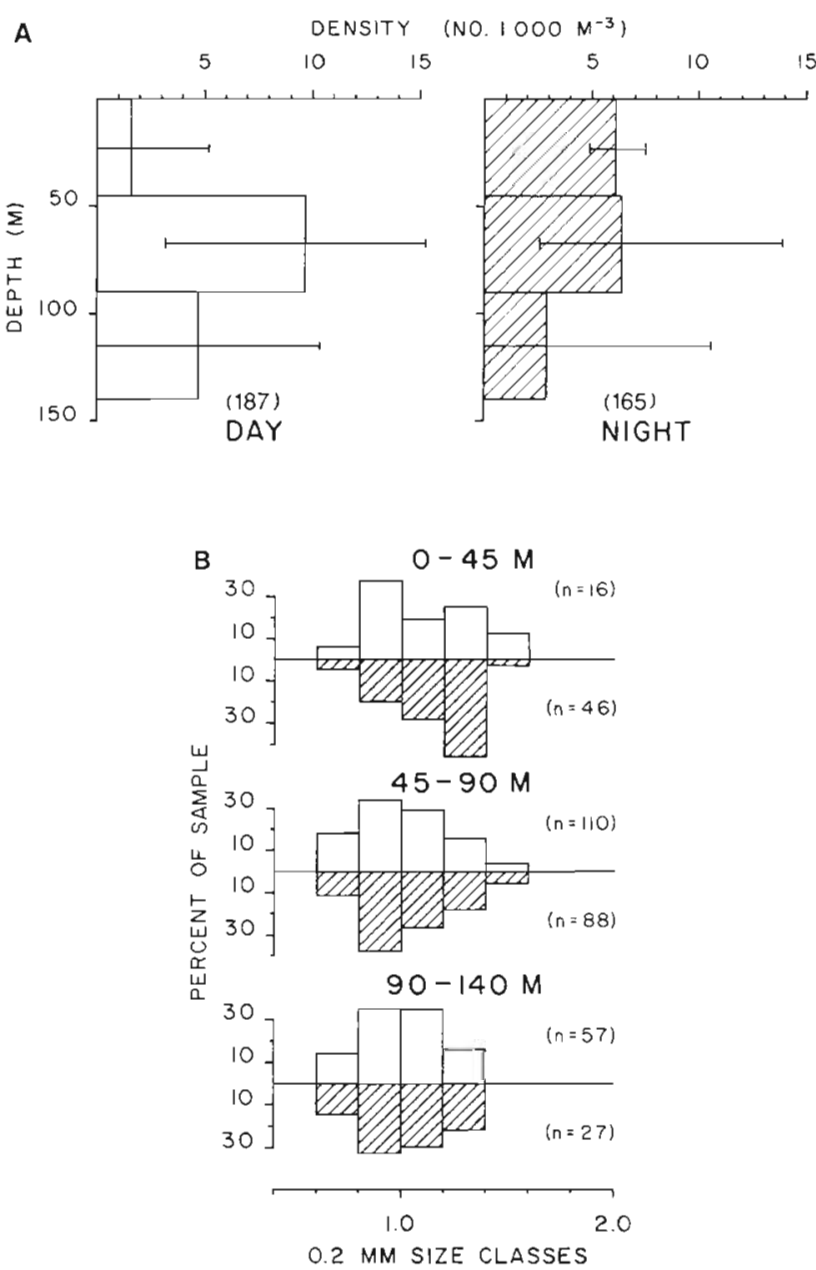

Fig. 6. Atlanta inflata. Legend as for Fig. 3

Despite high replicate variability, Atlanta plana exhibited significantly lower densities at night than during the day in the 45-90 and 90-140 m depth intervals (Fig. 12). In the $0-45 \mathrm{~m}$ interval the mean density was more than 3 times higher at night than during the day, although this difference was not significant. These results suggest a general upward night-time migration by the population, with most individuals concentrated in the upper $45 \mathrm{~m}$ of the water column. No statistically significant or apparent size differences were found between diel periods.

Three species (Pterotrachea hippocampus, Atlanta peroni and $A$. meteori) exhibited the greatest daytime depth range, extending from the surface to the 200-300 m depth interval (Figs. 13 to 15, respectively). These species also achieved the largest sizes among the heteropods studied. Between the 2 pterotracheids collected in the samples, the maximal size of $P$. hippocampus (39 mm; Fig. 13) was nearly twice that of the largest Firoloida desmaresti (23 mm; Fig. 7). A. meteori and $A$. peroni achieved the largest sizes among the
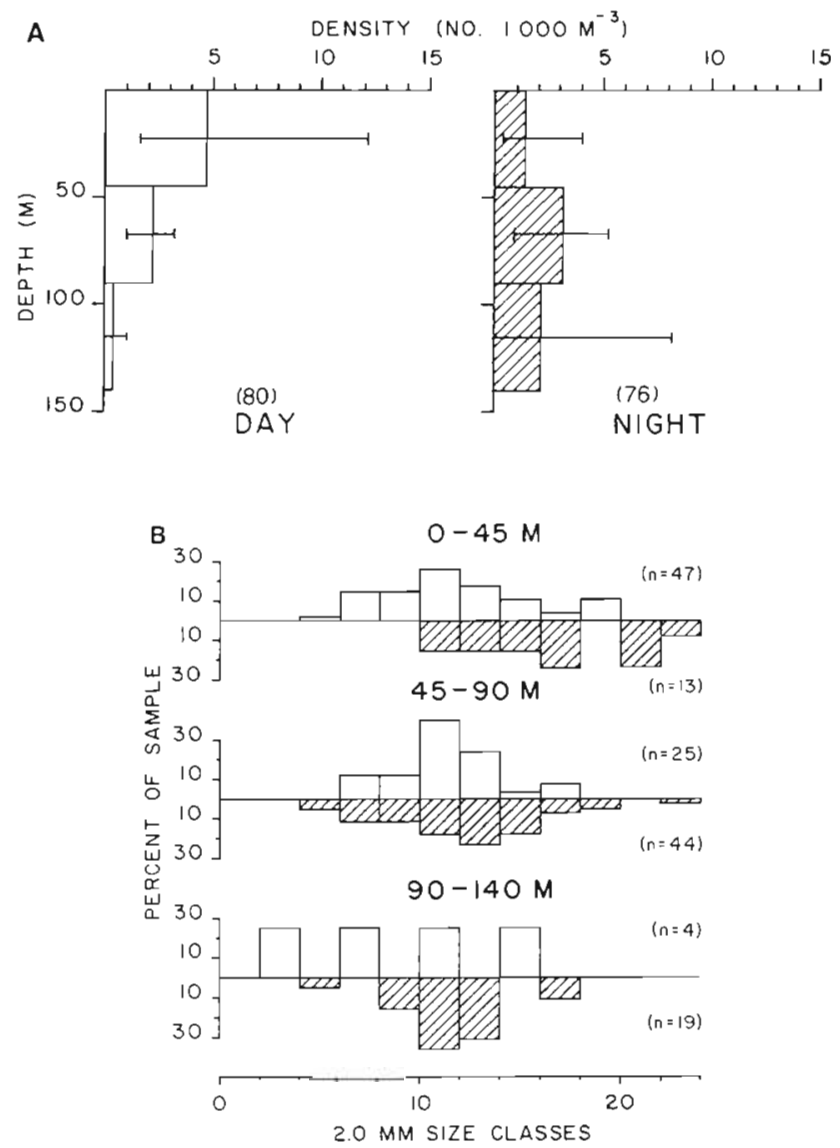

Fig. 7. Firoloida desmaresti. Legend as for Fig. 3

atlantids, attaining maximal shell lengths of 3.7 and $6.3 \mathrm{~mm}$, respectively (Figs. 14 and 15).

The highest daytime densities of Pterotrachea hippocampus occurred in the 90-140 m depth interval, while at night the greatest densities were obtained in the 0-45 $\mathrm{m}$ and 45-90 $\mathrm{m}$ intervals (Fig. 13). Densities in these latter 2 depth intervals were significantly higher at night. Although the numbers captured in the 90-140 and $140-200 \mathrm{~m}$ intervals were noticeably lower at night, the differences were not significant. Taken together, these data suggest an upward night-time migration of 50 to $100 \mathrm{~m}$ by a large portion of the population. Comparisons of the size-frequency distributions between diel periods revealed no significant differences for any of the depth intervals. However, in the depth intervals below $90 \mathrm{~m}$ the size classes between 14 and $25 \mathrm{~mm}$ were present in the daytime samples but were absent at night. Night-time samples shallower than $90 \mathrm{~m}$ included individuals in the $14-25 \mathrm{~mm}$ size classes. These results suggest an upward night-time migration of 50 to $200 \mathrm{~m}$ by individuals larger than about $14 \mathrm{~mm}$ (but less than $25 \mathrm{~mm}$ ) from daytime depths greater than $90 \mathrm{~m}$. Individuals greater than about $25 \mathrm{~mm}$ in diameter were present 

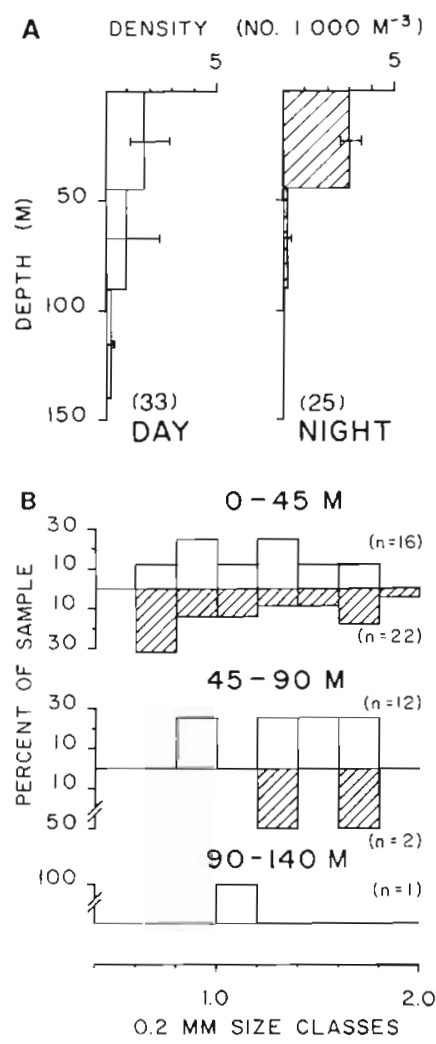

Fig. 8. Atlanta helicinoides. Legend as for Fig. 3

only between the surface and $90 \mathrm{~m}$ during both diel periods, which suggests that the largest members of the population are shallow non-migrators.

Atlanta meteori were recorded at low densities during the day between 45 and $300 \mathrm{~m}$, while at night none were captured below $140 \mathrm{~m}$, and most specimens $(85 \%$; based on the mean density values for each depth interval) were present in the upper $90 \mathrm{~m}$ (Fig. 14). Significantly greater densities occurred in the night-time samples in the 0-45 and 45-90 m intervals. Day and night size distributions were not significantly different for the 90-140 m interval, but were significantly different for the 45-90 m interval. The largest specimens in the 90-140 m interval at night did not exceed $1.4 \mathrm{~mm}$, while all daytime samples below $90 \mathrm{~m}$ included individuals greater than this shell diameter These data suggest an upward migration into the upper $90 \mathrm{~m}$ by individuals greater than about $1.4 \mathrm{~mm}$. An anomalous result from these size-frequency plots is that the largest specimens collected in the daytime tows did not exceed $2.4 \mathrm{~mm}$, while individuals exceeding this size were captured in night-time tows shallower than $90 \mathrm{~m}$.

Atlanta peroni was collected in daytime tows between 140 and $300 \mathrm{~m}$ and was not captured below $140 \mathrm{~m}$ at night (Fig. 15); a diel distribution pattern similar to that of $A$. meteori. In the depth intervals between the surface and $140 \mathrm{~m}$, there were no signifi-
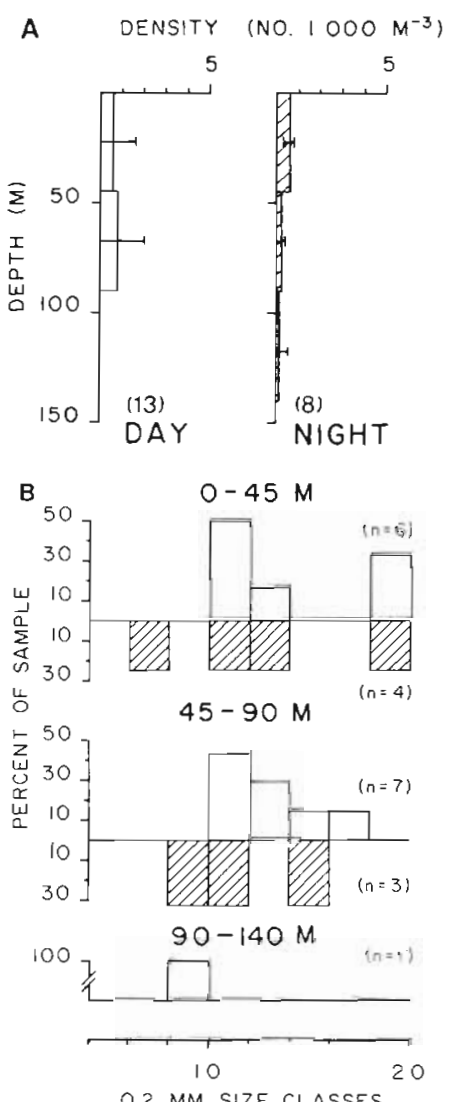

Fig. 9. Atlanta oligogyra. Legend as for Fig. 3

cant diel differences in density except for the $0-45 \mathrm{~m}$ depth interval. Thus, these data suggest an upward night-time migration into the upper $140 \mathrm{~m}$, with an increase in numbers in the upper $45 \mathrm{~m}$. The sizes of specimens captured in the day and night samples were not significantly different. During the day, however. individuals larger than $3.0 \mathrm{~mm}$ were present in the $45-90 \mathrm{~m}$ interval but were absent in the $0-45 \mathrm{~m}$ interval. At night individuals exceeding $3.0 \mathrm{~mm}$ were collected in the $0-45 \mathrm{~m}$ interval. These data suggest an upward migration by larger specimens from below $45 \mathrm{~m}$ during the day into the upper $45 \mathrm{~m}$ at night.

An overview of the distribution and abundance of the heteropod fauna was obtained by summing the mean densities of the atlantids and pterotracheids from each depth interval for each diel period (Fig. 16). The cumulative mean density was greatest for the $45-90 \mathrm{~m}$ depth interval during the day and for the $0-45 \mathrm{~m}$ interval at night. The vast majority of individuals $193 \%$ during the day and $99 \%$ at night) were collected in waters shallower than $140 \mathrm{~m}$. The cumulative mean densities were up to 10 times greater for the atlantids than the pterotracheids in depth intervals shallower than $140 \mathrm{~m}$. 

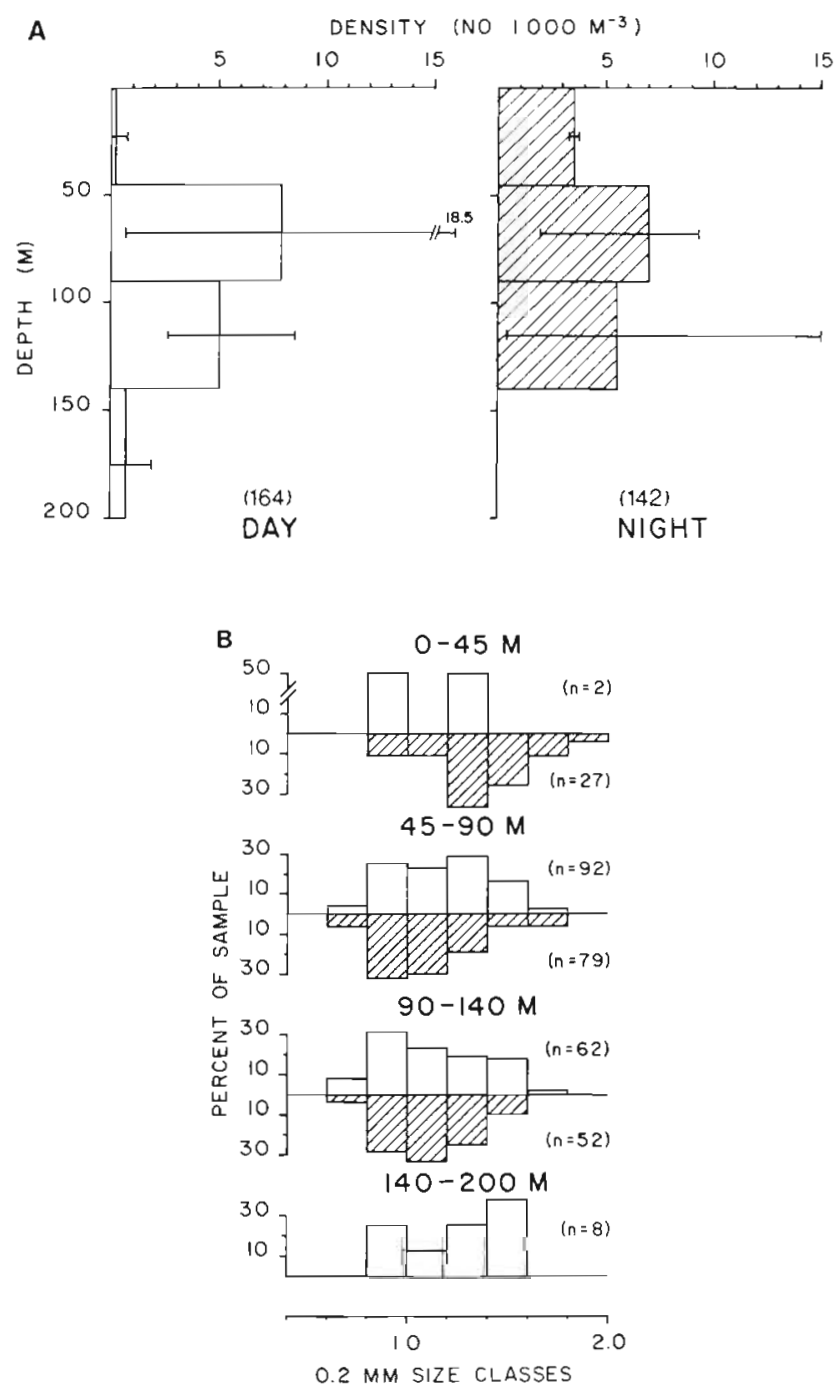

Fig. 10. Protatlanta souleyeti. Legend as for Fig. 3

\section{Net avoidance}

Among the heteropod species whose vertical distributions were analyzed above, all but two (Atlanta oligogyra and Firoloida desmaresti) exhibited nighttime increases in mean density in the upper $45 \mathrm{~m}$ of the water column. The observed night-time increases at shallow depths could have resulted from an upward night-time migration by the population or, alternatively, as a sampling artifact resulting from daytime net avoidance.

Comparisons of species densities in the upper $50 \mathrm{~m}$ during the day using $70 \mathrm{~cm}$ Bongo and $4 \mathrm{~m}^{2}$ ring nets (Table 1) reveal that three of the species (Protatlanta souleyeti, Atlanta peroni and A. meteori) were captured only by the ring net. The data for $P$. souleyeti provide support for an hypothesis of net avoidance. However, the data for $A$. peroni and $A$. meteori are
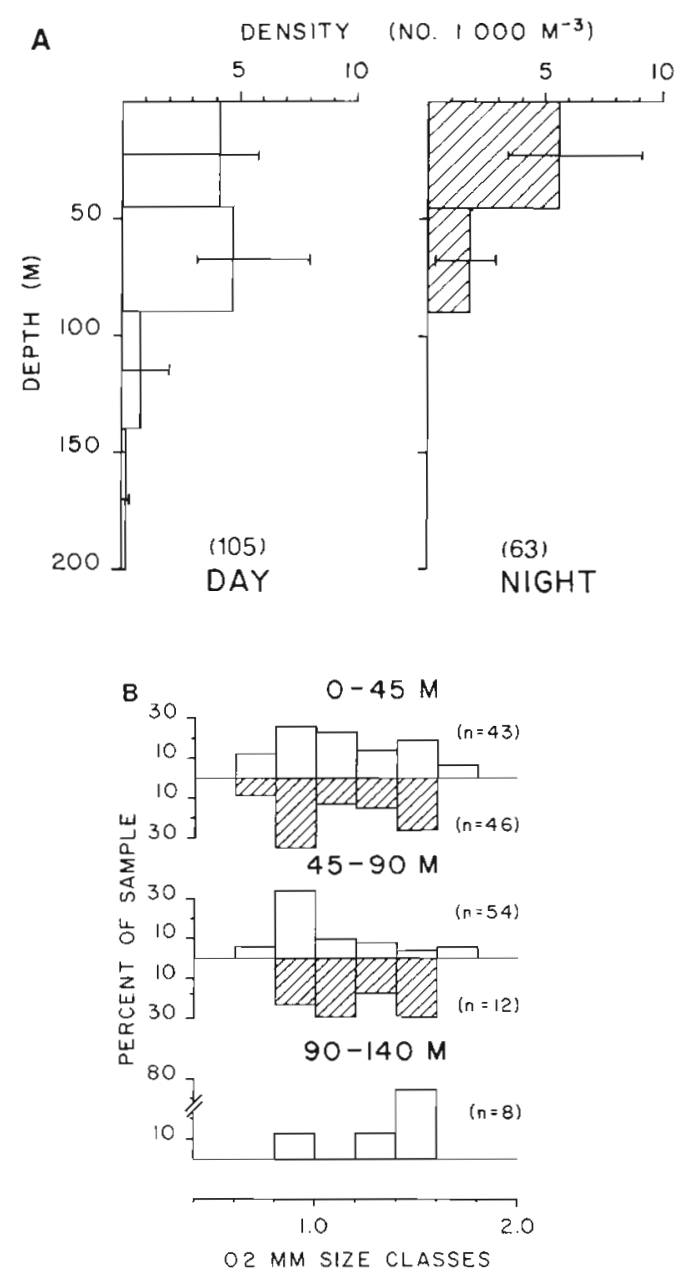

Fig. 11. Atlanta turriculata. Legend as for Fig. 3

inconclusive, due to the low numbers captured by the ring net and the fact that the volume of water filtered by the 2 types of nets was not equal. Among those species sampled by both nets, only $A$. inflata was captured in consistently higher densities by the ring net (densities greater than 5 individuals per $1000 \mathrm{~m}^{3}$ ) than by the Bongo nets (densities less than 4 per $1000 \mathrm{~m}^{3}$ ).

Hypothetically, if heteropods are capable of detecting and responding to an oncoming plankton net by actively swimming out of the path of the net, larger individuals should be more capable of avoiding capture than are smaller individuals. To test this hypothesis, comparisons were made of shell diameters of atlantids and body lengths of pterotracheids that were captured by the 2 types of nets. Because the Bongo nets did not collect Protatlanta souleyeti, Atlanta peroni or A. meteori, size comparisons could not be made for these species. Shell diameters of A. inflata were highly comparable between the 2 net types (Bongo nets: mean = $1.0 \mathrm{~mm}$, range $=0.7$ to $1.2 \mathrm{~mm}, \mathrm{n}=9$; ring net: mean $=$ $0.9 \mathrm{~mm}$, range $=0.7$ to $1.3 \mathrm{~mm}, \mathrm{n}=27$ ). Among the 


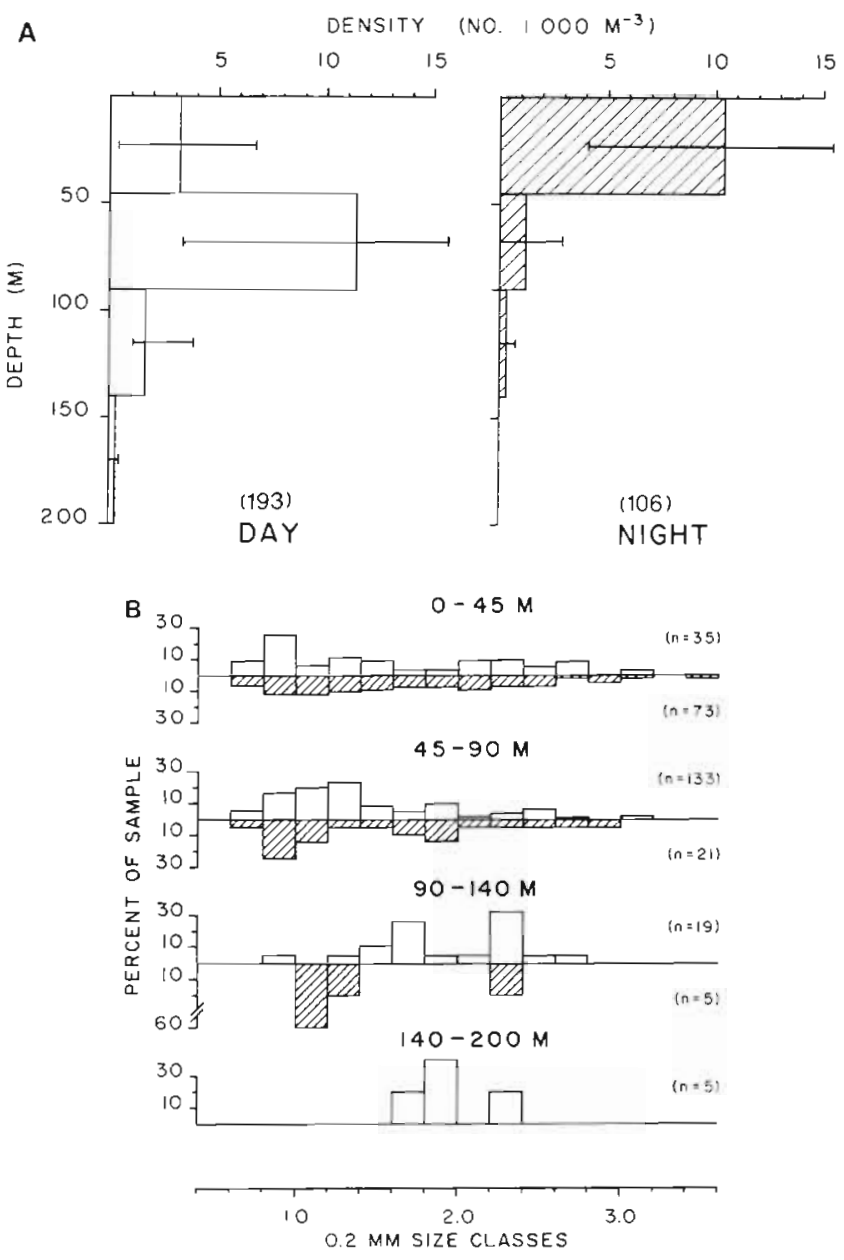

Fig. 12. Atlanta plana. Legend as for Fig. 3

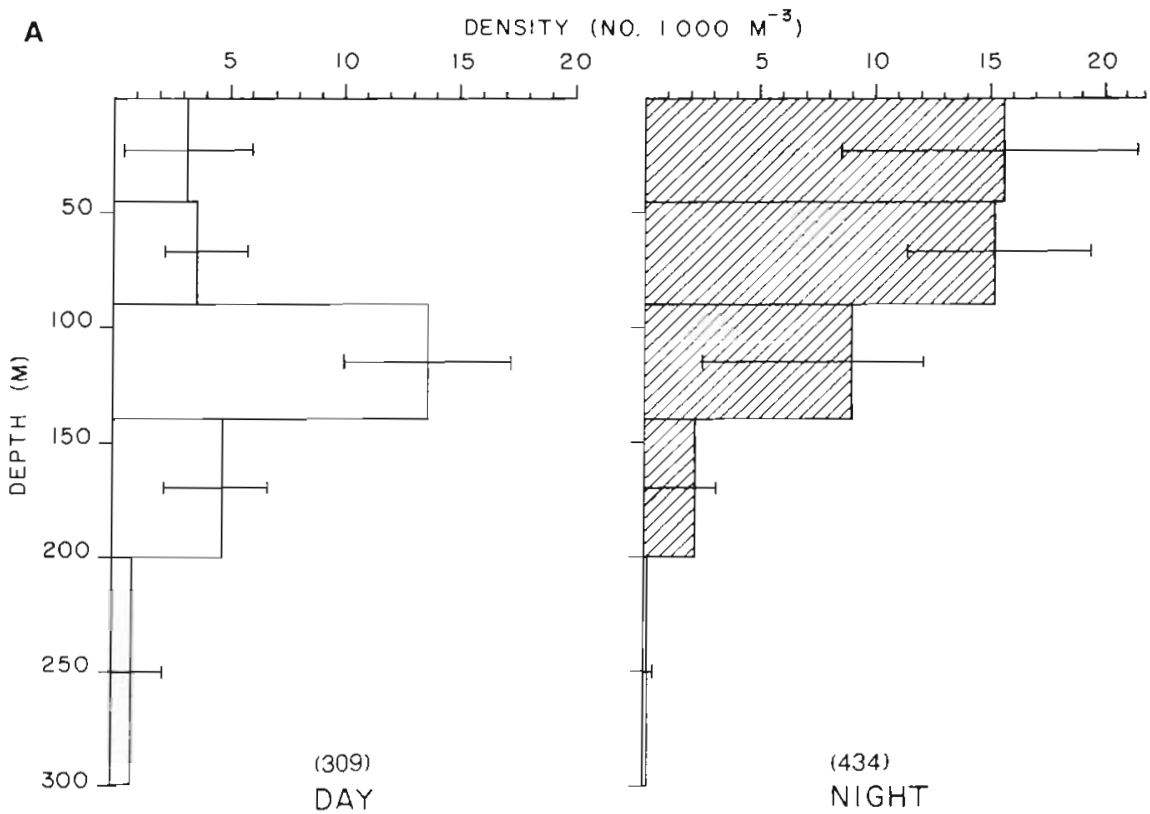

Fig 13. Pterotrachea hippocampus. Legend as for Fig. 3 remaining species, size differences were found only for Firoloida desmaresti (Fig. 17) Specimens captured by the ring net were larger, on average, and attained greater size (mean body length $=5.7 \mathrm{~mm}$; lengths to $16.0 \mathrm{~mm}$ ) than those in the Bongo net tows (mean = $3.8 \mathrm{~mm}$; only one individual greater than $7.0 \mathrm{~mm}$ ). Although the presence of specimens greater than $10 \mathrm{~mm}$ in the ring net samples would appear to support an hypothesis of Bongo net avoidance, these results may be somewhat misleading, since the ring net filtered a much greater volume of water and the probability is greater that larger individuals, which occur in low densities, will be captured less frequently by the Bongo nets.

As a test of whether or not any of those species that could avoid capture by the Bongo nets during the daytime could also avoid the $4 \mathrm{~m}^{2}$ net, a series of 7 day and 8 night oblique tows to a target depth of $300 \mathrm{~m}$ were compared (Table 2). None of the 12 species collected in this sample series were captured in significantly greater numbers during either day or night periods.

\section{DISCUSSION}

In terms of numbers of individuals, during the day more than $93 \%$ of the heteropods were captured in the upper $140 \mathrm{~m}$ of the water column, while at night more than $99 \%$ were taken within this depth range. Seven of the species (Oxygyrus keraudreni, Atlanta fusca, A.
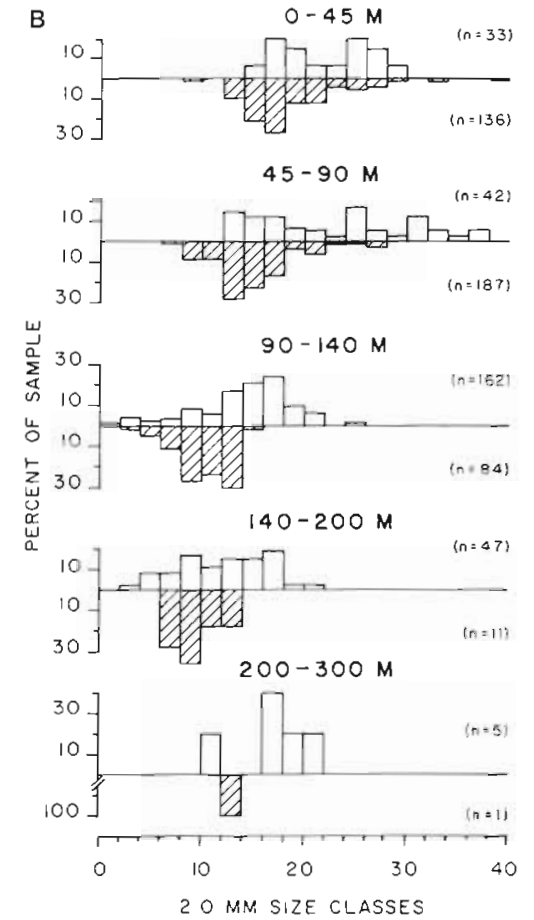

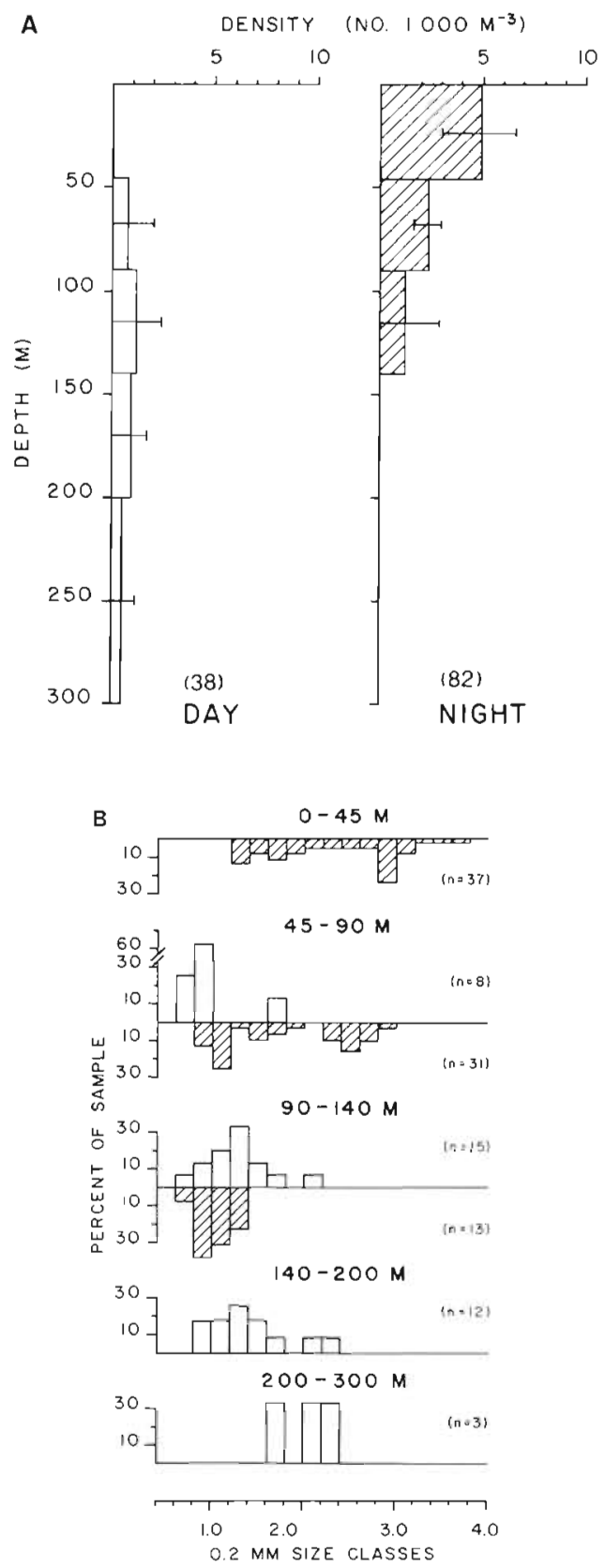

Fig. 14. Atlanta meteori. Legend as for Fig. 3

lesueuri, A. inflata, Firoloida desmaresti, A. helicinoides and $A$. oligogyra) were limited entirely to the upper $140 \mathrm{~m}$, while 3 species (A. turriculata, Protatlanta souleyeti and A. plana) were captured primarily between the surface and $140 \mathrm{~m}$ during the day. Most of these species were small; 8 had maximal shell diameters of $2.0 \mathrm{~mm}$ or less, while 210 . keraudreni and $A$ plana) had maximal diameters of 2.8 and $3.6 \mathrm{~mm}$, respectively. Also, differences in the diel vertical distributions of only 3 of these species ( $A$. helicinoides, $A$. turriculata and $A$. planal suggested a limited upward migration at night by a portion of each population. The
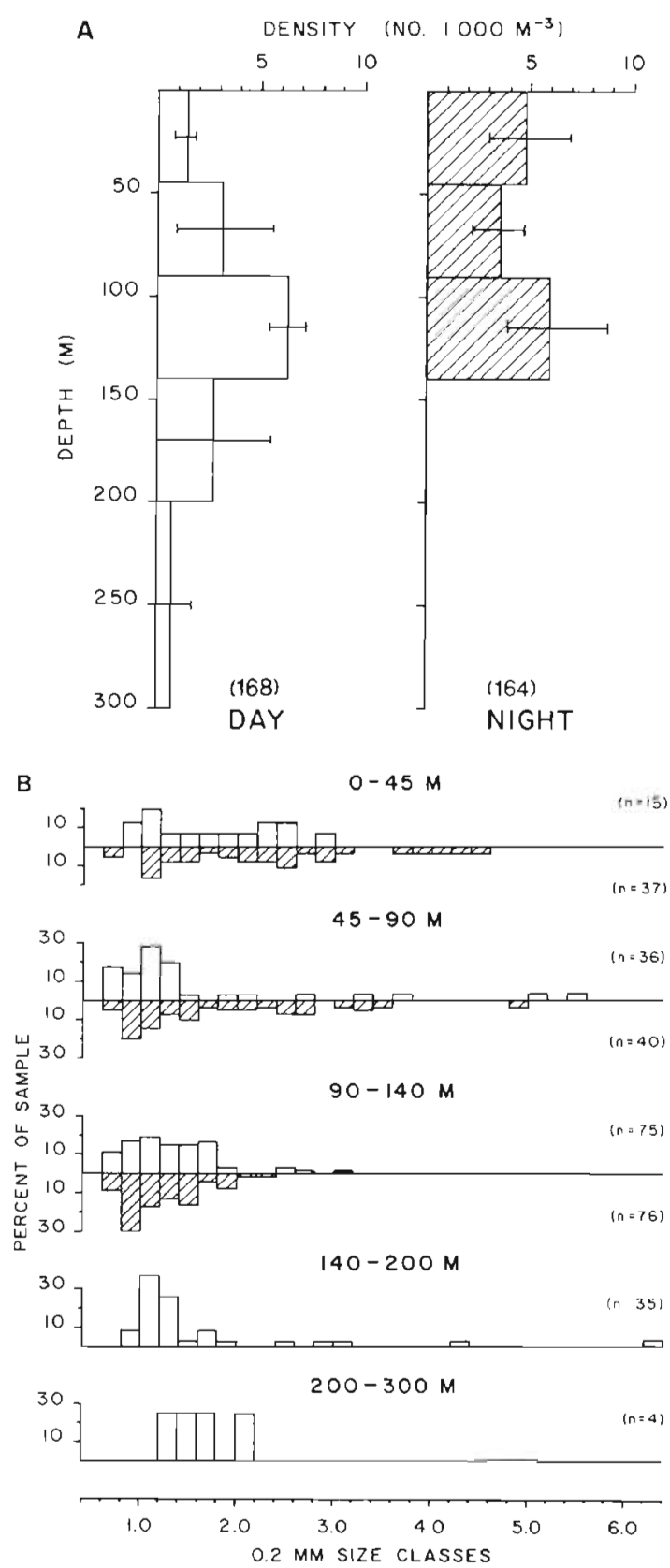

Fig. 15. Atlanta peroni. Legend as for Fig. 3

remaining 3 species (Pterotrachea hippocampus, A. meteori and $A$. peroni) ranged below $200 \mathrm{~m}$ during the day and appeared to migrate toward the surface at night. This latter group of species achieved the largest sizes among the pterotracheids (to $40 \mathrm{~mm}$ for $P$. hippocampus) and among the atlantids (to $3.8 \mathrm{~mm}$ for $A$. meteori and $6.4 \mathrm{~mm}$ for $A$. peroni). Thus, the largest and deepest-dwelling species displayed nocturnal vertical migration patterns. For some species data on vertical migration were complicated by possible daytime net avoidance in the upper depth layer. However, for most of the species that appeared to exhibit vertical 


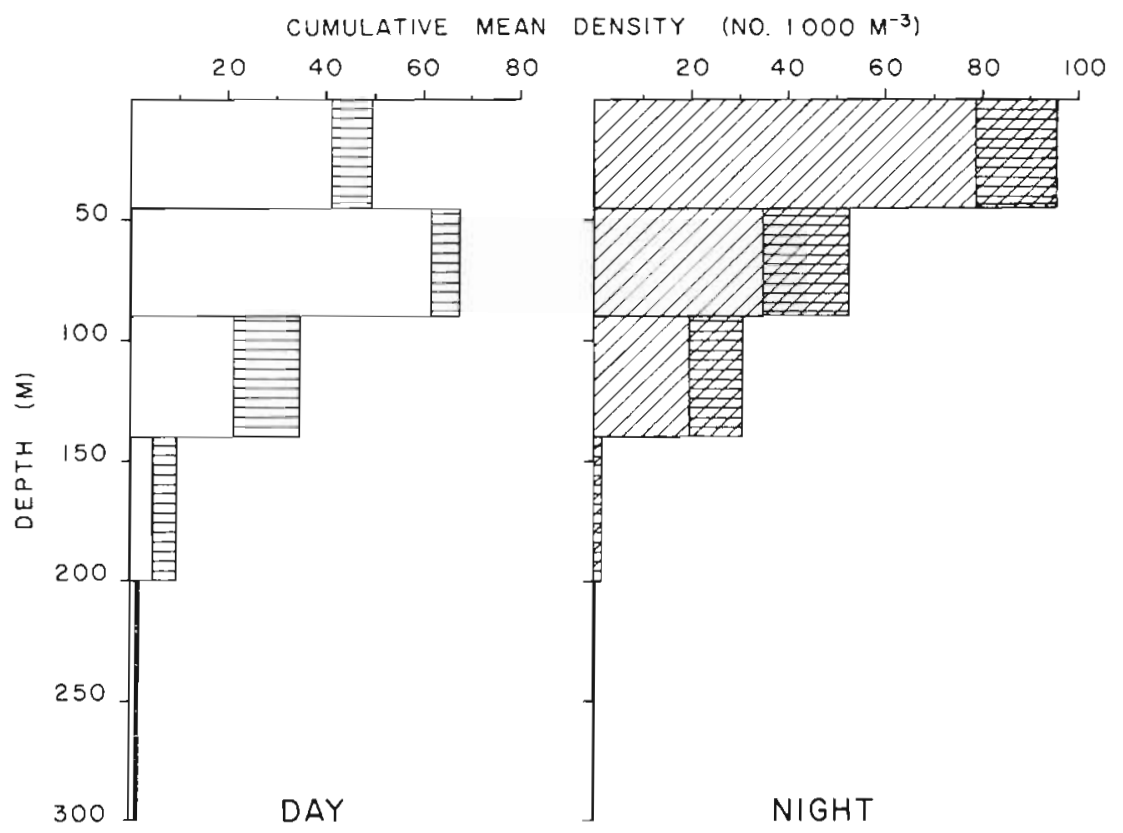

Fig. 16. Cumulative mean densities (expressed as combined numbers $1000 \mathrm{~m}^{-3}$ ) in each depth interval during day (open bars) and night (diagonally hatched bars). Cumulative mean densities of the Pterotracheidae (horizontally hatched) are distinguished from the Atlantidae (open bars) in each depth interval

movement, the more convincing evidence was the diel differences in the deeper range of the populations. In terms of both numbers of species and individuals, therefore, the majority of the epipelagic heteropods from Hawaiian waters (1) dwell in the upper portion $(0$ to $140 \mathrm{~m}$ ) of the epipelagic zone, (2) do not exhibit diel migration behavior, and (3) are those species within the Pterotracheidae and Atlantidae that do not attain large sizes.

The above conclusion that the majority of epipelagic heteropods are non-migrators is supported by the in situ field behavioral observations of shallow-water atlantids by Gilmer (in Lalli \& Gilmer 1989). During the day undisturbed specimens normally swam at rates of 2 to $3 \mathrm{~cm} \mathrm{~s}^{-1}$. If disturbed, however, they could swim at least 3 times this fast. At night the behavioral patterns were quite different. The atlantids were inactive, hanging motionless from long mucus strands (up to $0.5 \mathrm{~m}$ in Oxygyrus keraudreni) that appeared to have been produced by the foot. This diel behavior pattern is well suited for predators that utilize downwelling sunlight during the daytime to locate and pursue their prey. Daytime, visual location of prey by Cardiapoda placenta has been reported by Hamner et al. (1975). This species of carinariid locates prey positioned above itself and silhouetted against the downwelling light, and then swims rapidly upward as far as $60 \mathrm{~cm}$ to capture the prey. The heteropods possess image-form-

Table 1. Comparisons of the densities (numbers $1000 \mathrm{~m}^{-3}$ ) of heteropod species captured in oblique tows using $70 \mathrm{~cm}$ Bongo and $4 \mathrm{~m}^{2}$ ring nets towed obliquely to a target depth of $50 \mathrm{~m}$ during daytime on 23 November 1986

\begin{tabular}{|c|c|c|c|c|c|c|c|c|}
\hline \multirow[t]{2}{*}{ Species } & \multicolumn{4}{|c|}{ Bongo samples } & \multicolumn{4}{|c|}{ Ring net samples } \\
\hline & 1 & 2 & 3 & Mean & 1 & 2 & 3 & Mean \\
\hline Atlanta lesueuri & 28.2 & 47.9 & 41.0 & 39.0 & 27.3 & 24.3 & 22.5 & 24.7 \\
\hline Atlanta turriculata & 4.7 & 23.0 & 21.8 & 16.5 & 11.3 & 8.6 & 4.8 & 8.2 \\
\hline Firoloida desmarestl & 8.2 & 9.2 & 17.1 & 11.5 & 7.3 & 11.3 & 12.4 & 10.3 \\
\hline Atlanta oligogyra & 118 & 10.1 & 6.8 & 9.6 & 4.2 & 3.6 & 4.6 & 4.1 \\
\hline Atlanta plana & 2.4 & 3.7 & 4.1 & 3.4 & 2.2 & 0.5 & 1.0 & 1.2 \\
\hline Atlanta inflata & 1.2 & 2.8 & 3.4 & 2.5 & 8.0 & 7.0 & 5.4 & 6.8 \\
\hline Atlanta helicinoides & 1.2 & 1.8 & 2.7 & 1.9 & 1.8 & 1.7 & 1.0 & 1.5 \\
\hline Allanta echinogyra & 0 & 0 & 2.7 & 1.3 & 1.8 & 0.7 & 0.4 & 1.0 \\
\hline Protatlanta souleyeti & 0 & 0 & 0 & 0 & 6.2 & 2.4 & 4.4 & 4.3 \\
\hline Atlanta peroni & 0 & 0 & 0 & 0 & 0.9 & 0.2 & 0.4 & 0.5 \\
\hline Atlanta meteori & & 0 & 0 & 0 & 0 & 0.2 & 0.2 & 0.1 \\
\hline Volume filtered (m3) & 1700 & 1086 & 1465 & 1417 & 4508 & 5841 & 4986 & 5112 \\
\hline Maximal net depth (m) & 42 & 40 & 38 & 40 & 50 & 50 & 50 & 50 \\
\hline
\end{tabular}




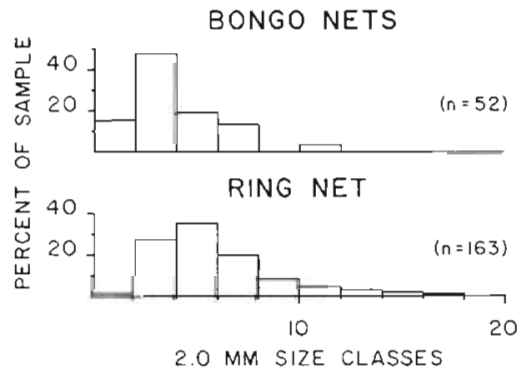

Fig. 17. Firoloida desmaresti. Comparison of the sizes (body length; grouped into $2.0 \mathrm{~mm}$ size classes) captured by open $70 \mathrm{~cm}$ Bongo and $4 \mathrm{~m}^{2}$ ring nets. Three replicate oblique tows from the surface to a target depth of $50 \mathrm{~m}$ were taken with each net type. Numbers of measured specimens are given in parentheses

Table 2. Comparison of densities (numbers $50 \mathrm{~m}^{-2}$ ) of heteropod species between day and night periods based on oblique tows made with a $4 \mathrm{~m}^{2}$ ring net to a target depth of $300 \mathrm{~m}$ on 24 and 25 March 1986. Differences in densities between day and night tows were assessed by the Mann Whitney U statistic. ns: not significant ( $p>0.05$ )

\begin{tabular}{|lrrrrr|}
\hline Species & \multicolumn{2}{c}{$\begin{array}{c}\text { Day } \\
(\mathrm{n}=8)\end{array}$} & \multicolumn{2}{c|}{$\begin{array}{c}\text { Night } \\
(\mathrm{n}=7)\end{array}$} & Signif. \\
& Mean & $\mathrm{SD}$ & Mean & $\mathrm{SD}$ & \\
\hline Atlanta peroni & 30.1 & 11.8 & 25.0 & 8.1 & $\mathrm{~ns}$ \\
Atlanta plana & 18.5 & 8.2 & 28.7 & 8.8 & $\mathrm{~ns}$ \\
Atlanta inflata & 17.7 & 5.9 & 19.4 & 10.8 & $\mathrm{~ns}$ \\
Protatlanta souleyeti & 15.6 & 6.5 & 10.0 & 5.5 & $\mathrm{~ns}$ \\
Atlanta turriculata & 7.2 & 1.3 & 8.4 & 4.3 & $\mathrm{~ns}$ \\
Atlanta lesueuri & 5.2 & 3.6 & 6.5 & 4.9 & $\mathrm{~ns}$ \\
Atlanta meteori & 4.9 & 3.0 & 5.0 & 3.0 & $\mathrm{~ns}$ \\
Atlanta helicinoides & 1.9 & 1.5 & 2.3 & 1.7 & $\mathrm{~ns}$ \\
Atlanta fusca & 1.8 & 2.0 & 1.9 & 1.7 & $\mathrm{~ns}$ \\
Atlanta inclinata & 1.3 & 1.1 & 1.1 & 1.0 & $\mathrm{~ns}$ \\
Atlanta oligogyra & 0.5 & 0.5 & 1.4 & 2.0 & $\mathrm{~ns}$ \\
Oxygyrus keraudreni & 0.1 & 0.3 & 0.3 & 0.7 & $\mathrm{~ns}$ \\
& & & & & \\
\hline
\end{tabular}

ing eyes (Land 1980), although the eye morphology is extremely unusual in that the retina is narrow and strip-like (Dilly 1969, Land 1980). The visual limitations of such a retina are overcome, at least in Oxygyrus keraudreni and several undesignated species of Atlanta, by the use of scanning eye movements; a rapid rotation of the eyes downward from just above the horizontal to below the vertical, followed by a slow upward movement (Land 1982). Presumably, prey are located while the eyes are scanning slowly upward.

The activity patterns of the larger, gelatinous heteropods (in the families Carinariidae and Pterotracheidae) during the day appear to differ from the continuous swimming of the negatively buoyant atlantids. The species observed by Gilmer (in Lalli \& Gilmer 1989) were found to be neutrally buoyant and inactive much, if not most, of the time. In situ, daytime observa- tions of Cardiapoda placenta and Pterotrachea coronata by Hamner et al. (1975) revealed that active swimming only occurred when the heteropods were in pursuit of prey. Apparently, neutral buoyancy is achieved in these animals by regulation of the ion content of their enlarged gelatinous bodies (as shown for P. coronata by Denton \& Shaw 1961). Thus, unlike the atlantids, the gelatinous heteropods would not appear to be restricted in their night-time activities. However, nocturnal predation would not appear to be feasible unless these species have particularly acute vision, which would enable them to detect prey at low light levels (e.g. in shallow waters on bright, moonlit nights), or if they feed on bioluminescent prey. The deepest-dwelling species from the present study (Pterotrachea hippocampus, Atlanta meteori and A. peroni) appeared to undergo upward vertical migrations at night. Also, 2 other species (A. turriculata and A. plana) appeared to make shorter upward nocturnal excursions. By living at greater depths during the day, these heteropods may be under reduced predation pressure from visual predators, which appear to be mainly actively-foraging fishes (Lalli \& Gilmer 1989). The active maintainance of a vertical body orientation by certain pterotracheids at night, with their ventral swimming fin directed downward and their eyes positioned in a forward to downward-directed orientation (Gilmer, in Gilmer \& Lalli 1989), suggests that some pterotracheids, at least, may search for bioluminescent prey.

The results of the net avoidance study suggested that at least one species of atlantid, Protatlanta souleyeti, and possibly several others (e.g. Atlanta inflata, A. peroni and $A$. meteori) were able to avoid capture by $70 \mathrm{~cm}$ Bongo nets in shallow waters during the day. Net avoidance by several species of atlantids was also suggested in a previous study (McGowan \& Fraundorf 1966), which compared 6 different sizes of nets (ranging in mouth diameter from 20 to $140 \mathrm{~cm}$ ), towed obliquely to a depth of $140 \mathrm{~m}$ in 4 series of tows (2 day and 2 night). The largest net consistently captured greater numbers of $A$. gaudichaudi. Results for 3 other species (A. inflata, A. peroni and A. lesueuri) were suggestive of net avoidance, but were inconsistent, due to high replicate variability (as found in the present study).

The vertical distributions of individual heteropod species reported here can be compared with the results from only 3 previous studies. Off Hawaii Oxygyrus keraudreni ranged downward to a maximal depth of $90 \mathrm{~m}$, and nearly all specimens ( 8 of 9 ) were captured in the upper $45 \mathrm{~m}$ of the water column. In close agreement, Richter (1982) found that O. keraudreni from the Indian Ocean was essentially restricted to the upper $100 \mathrm{~m}$ of the water column, and that nearly $90 \%$ of the 
captured individuals occurred between the surface and $50 \mathrm{~m}$. Pafort-van Iersel (1983) reported that Pterotrachea hippocampus and $P$. minuta (which Seapy [1985] considers a junior synonym of $P$. hippocampus) from the North Atlantic were largely limited to the upper $200 \mathrm{~m}$ of the water column. In Hawaiian waters $P$. hippocampus was recorded mainly in the upper $200 \mathrm{~m}$, although low densities were recorded below this depth. Lastly, the vertical distribution patterns for 6 of the atlantid species included in this study can be compared with results obtained by Richter (1974) for these same species from the Indian Ocean. Based on differences in mean densities of species captured by vertical tows taken to $100 \mathrm{~m}$ and to between 200 and $400 \mathrm{~m}$, Richter concluded that Atlanta inflata exhibited no depth preference, that $A$. peroni, $A$. turriculata and A. oligogyra preferred shallower $(<100 \mathrm{~m})$ depths, and that $A$. lesueuri and $A$. meteori preferred deeper $(>100 \mathrm{~m}$ ) waters. Results from the present study are in agreement with Richter for all of the above species except for $A$. peroni (since the daytime range extended below $200 \mathrm{~m}$ ) and $A$. lesueuri (since the majority of the population was recorded between the surface and $90 \mathrm{~m}$ ). Despite the limited data upon which Richter's analyses were based and possible regional differences between the species, his distributional results agreed remarkably well with those of the present study.

Acknowledgements. The support of the officers, crew and members of the scientific party during cruises of the RV 'Kana Keoki' and RV 'Kila' are gratefully acknowledged. These cruises were undertaken in conjunction with Richard Young of the University of Hawaii, whose collaboration is greatly appreciated. I extend my thanks to Jed Hirota for loan of the Bongo nets, to Robert Harman who supervised the sampling program during the April 1984 cruise, and to Tina Hartney, Richard Young, John McGowan and Charles Miller for their critiques of the manuscript. This study was supported by National Science Foundation Grant OCE-8500593.

\section{LITERATURE CITED}

Blackburn, M. (1956). Sonic scattering layers of heteropods. Nature, Lond. 177. 374-375

Daniel, W W. (1978). Applied nonparametric statistics. Houghton Mifflin, Boston

Denton, E. J., Shaw, T I. P. (1961). The buoyancy of gelatinous marine animals. J. Physiol, Lond. 161. 14P-15P (Proceedings)

This article was presented by Dr M. R. Landry. Honolulu, Hawaii, USA
Dilly, P. N. (1969). The structure of a photoreceptor organelle in the eye of Pterotrachea mutica. Z. Zellforsch. mikrosk. Anat. 99: $420-429$

Hamner, W. M., Madin, L. P., Alldredge, A. L., Gilmer, R. W. Hamner, P. P. (1975). Underwater observations of gelatinous zooplankton: sampling problems, feeding biology, and behavior Limnol. Oceanogr. 20: 907-917

Lalli, C. M., Gilmer, R. W. (1989). Pelagıc snails. The biology of holoplanktonic gastropod mollusks. Stanford University Press, Stanford

Land, M. F. (1980). Optics and vision in invertebrates. In: Autrum, H. (ed.) Handbook of sensory physiology VII/6B. Springer-Verlag, Berlin, p. 471-592

Land, M. F. (1982). Scanning eye movements in a heteropod mollusc. J. exp. Biol. 96: 427-430

McGowan, J. A., Fraundorf, V. J. (1966). The relationship between size of net used and estimates of zooplankton diversity. Limnol. Oceanogr $11 \quad 456-469$

Pafort-van Iersel, $T$ (1983). Distribution and variation of Carinaridae and Pterotracheidae (Heteropoda, Gastropoda) of the Amsterdam Mid North Atlantic Plankton Expedition 1980. Beaufortia 33: 73-96

Raymont, J. E. G. (1983). Plankton and productivity in the oceans, 2nd edn. Vol. 2, Zooplankton. Pergamon Press, New York

Richter, G. (1974). Die Heteropoden der 'Meteor'-Expedition in den Indischen Ozean 1964/65. 'Meteor' Forsch-Ergebn. 17: $55-78$

Richter, G. (1982). Mageninhaltsuntersuchungen an Oxygyrus keraudreni (Lesueur) (Atlantidae. Heteropoda). Beispiel einer Nahrungskette im tropischen Pelagial. Senckenberg. maritima 14: 47-77

Seapy, R. R. (1985). The pelagic genus Pterotrachea (Gastropoda: Heteropoda) from Hawaiian waters: a faunistic survey. Malacologia 26: 125-135

Seapy, R. R. (1987). The heteropod fauna of oceanic waters off Hawaii. A. Rep. West. Soc. Malacologists 19: $9-12$

Seapy, R. R. (in press). The pelagic family Atlant1dae (Ciastropoda: Heteropoda) from Hawaiian waters: a taxonomic review. Malacologia

Spoel, S. van der (1976). Pseudothecosomata, Gymnosomata and Heteropoda (Gastropoda). Bohn, Scheltema and Holkema, Utrecht

Taylor, D., Berner, L. Jr. (1970). The Heteropoda (Mollusca Gastropoda). In: Pequegnat, W S., Chace, F. A. Jr (eds.) Contributions on the biology of the Gulf of Mexico. Texas A \& M Univ. Oceanogr. Studies, Vol I. Gulf Publ. Co., Houston, p. 231-244

Tesch, J. J. (1949). Heteropoda. Dana Rep. 34. 1-53

Thiriot-Quiévreux, C. (1968). Variations saisonnieres des Mollusques dans le plancton de la region de Banyuls-sur-Mer (zone sud du Golfe du Lion) Novembre 1965 - Decembre 1967 Vie Milieu Ser B: Oceanogr. 19 (1B): 35-83

Young, R. E., Kampa, E. M., Maynard, S. D., Mencher, F. M., Roper, C. F. E. (1980). Counterillumination and the upper depth limits of midwater animals. Deep Stac Res. 27 A: $671-691$

Manuscript first received: June 7, 1989

Revised version accepted: November 17, 1989 